\title{
FACTORS INFLUENCING THE STATUS OF EASTERN AND MOUNTAIN BLUEBIRDS IN SOUTHWESTERN MANITOBA
}

\author{
by Wayne Miller, 2 Almond Crescent, Brandon, Manitoba
}

Several authors have intimated that the Mountain Bluebird (Sialia currocoides) successfully competes with the Eastern Bluebird (Sialis sialis) in areas of range overlap. For example, Lawrence (1947) has suggested that gains in territory for Mountain Bluebirds are "generally made at the expense of the russetbreasted Eastern Bluebird."

The history of the occurrence of bluebirds in Manitoba offers opposing arguments with regard to the above possibility. Criddle (1904) found Mountain Bluebirds "by no means uncommon" in the Spruce Woods Forest Reserve in the 1890 's. At the same time, however, the Eastern Bluebird was expanding its range to include such areas as Portage la Prairie and Carberry (the latter on the northern edge of the Spruce Woods!) (Thompson, 1891). In fact, Thompson (1893) later states: "this species, [sialis] instead of [being] very rare, has become quite common in the country along the Assiniboine ..." Certainly, the fact that Eastern Bluebirds could expand their range to include areas of Mountain Bluebird occupation and at the same time increase their numbers does not support the hypothesis.

On the other hand, Criddle (1927: 40) later commented on the interactions between sialis and currocoides in a manner which suggests that territorial interactions between bluebird species affected their relative populations: "One pair of Mountain Bluebirds came to us about the year 1912 when they successfully fought for possession of a box with a pair of Eastern Bluebirds. The two continued as neighbours ... but as the western birds increased the eastern ones diminished in numbers, until in 1925 our boxes were occupied by Mountain Bluebirds alone."

The existence of apparently conflicting data such as the above points out a need for investigation into the influence of interspecific interaction on the status of Eastern and Mountain bluebirds in an area of range overlap.

\section{Study Area and Study Resources}

This present study of bluebird interactions was conducted in southwestern Manitoba, generally about Brandon. Several factors make this area somewhat unique for such a study in comparison to the rest of Canada.

Although the breeding ranges of Mountain and Eastern bluebirds overlap in southwestern Manitoba and southern Saskatchewan (see Godfrey, 1966), the breeding populations of Eastern Bluebirds in Saskatchewan are not sufficient to produce largescale interaction with Mountain Bluebirds (see Belcher, 1966). East of Brandon as the eastern fringe to the Mountain Bluebird's range is approached, Mountain Bluebird numbers diminish appreciably. Therefore, the relatively small area between Carberry and Virden appears to be the only point in Canada where interactions between these two bluebirds can be observed on a large scale. In addition, both sialis and currocoides have increased their numbers near Brandon in recent years.

In $1959, \mathrm{Mr}$. John Lane and a group of boys began what developed into a 1700-box nest line by 1968 in southwestern Manitoba. Figure 1 shows the extent of this nest line. Between 1966 and 1968 I recorded observations of bluebird behaviour on this nest line.

In 1969 , I studied the reproductive success and territorial interactions of sialis and currocoides in an area near Camp Hughes. Camp Hughes (Fig. 1 "A"), located on the northern edge of the Spruce Woods Forest Reserve, comprises a mixture of Stipa-Andropogon Sand Prairie, Aspen Poplar Forest, and White Spruce Sand 
Hill Community (after Bird, 1961). This area holds a high concentration of bluebirds in comparison to the rest of the rest line, largely because this combination of habitats, which appears to be desirable to both bluebird species, seldom occurs elsewhere in southwestern Manitoba. Judging from observations on the nest line, bluebirds prefer sandy areas of short grass prairie with moderate amounts of aspen cover.

Near Camp Hughes, nest boxes were erected on fences along roadways and a railway. In most cases, utility lines ran above or near the nest sites, providing over-head perches. This area was visited once weekly during the nesting season.

\section{Present Bluebird Populations}

The results in Table 1 (compiled from the Annual Reports of the Brandon Junior Birders' Club and from the original data for the nest line) indicate present trends in relative bluebird populations about Brandon. Over the six-year period included in this table, bluebirds of both species became more common, initially using 6.7 per cent of available nest sites, and ultimately 21.3 per cent. Due to the specialized nesting requirements of both sialis and currocoides (discussed under "Nest Requirements . . ") I suspect that comparative figures for more natural conditions would be considerably lower, but nonetheless proportional. Although Eastern Bluebirds increased fairly steadily up to 1966, Mountain Bluebirds became more dominant in "per cent of bluebird total that were currocoides" (currocoides) 56.0 per cent for 1963, 80.1 per cent for 1968). This suggests that acceleration of the population growth for sialis was impeded for various reasons. The greater success of currocoides is further demonstrated by the rise from 3.7 per cent to 17.3 per cent for the "per cent of total boxes checked that were currocoides," when compared to sialis which reached a maximum of 5.9 per cent (1966). After 1966, sialis populations declined (see Fig. 2).

The following discussion will consider whether the decline of Eastern

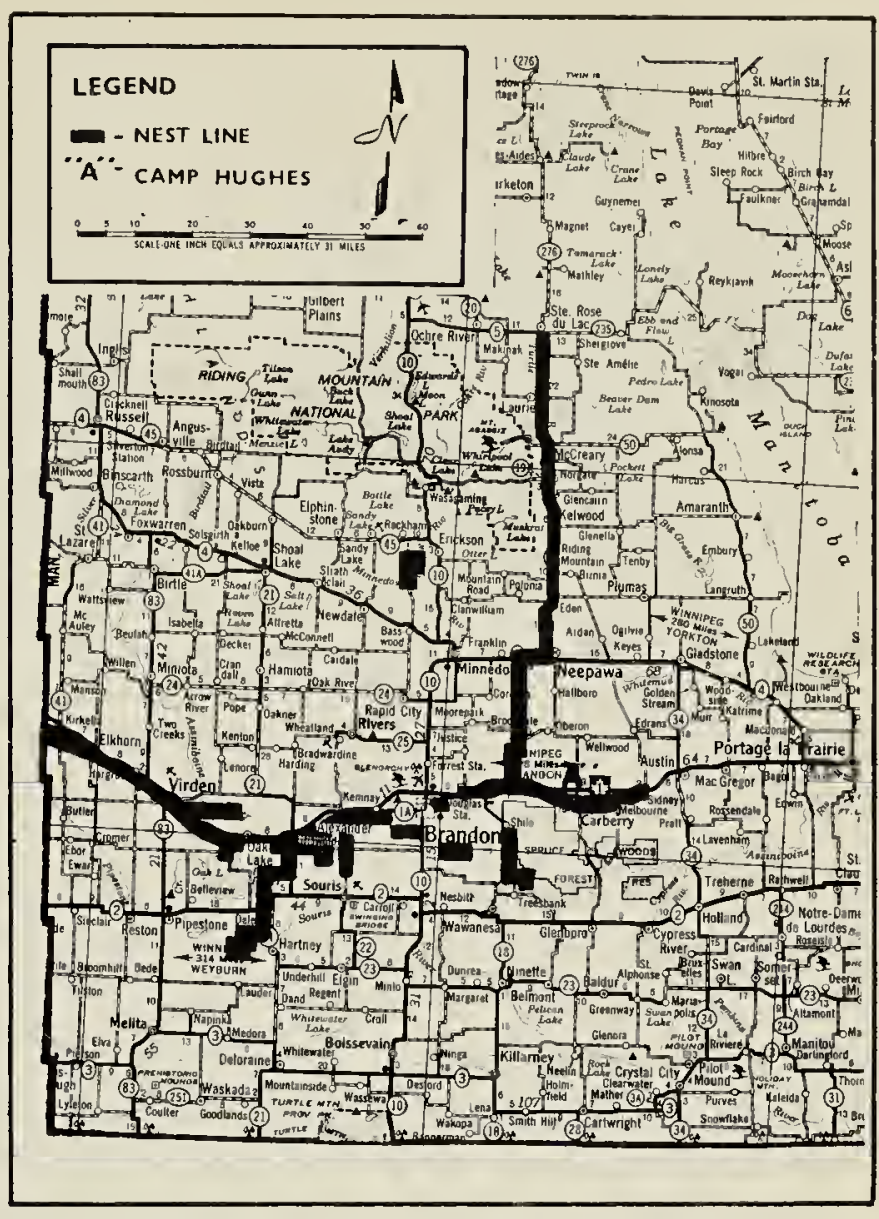

Fig. 1. Map of southwestern Manitoba showing the extent of the nest line in 1968 and the Camp Hughes study area.

Bluebirds is solely accounted for by interactions with Mountain Bluebirds, or whether other factors contributed. 1) Nest requirements and availability of nest sites

Throughout the nest line it was found that bluebird populations were highest in areas where aspen woodland intersected sand prairie (for example, Oak Lake, Camp Hughes, Melbourne, Grand Clarier). Eastern Bluebirds favoured the use of woodland retreats and consequently their nests were generally located nearer woodlands than those of Mountain Bluebirds. This trend was evident at Camp Hughes in 1969.

Both bluebird species preferred a deep nest cavity, although Mountain Bluebirds were observed to nest in shallow boxes on numerous occasions, whereas Easterns used these rarely. The presence of tall weedy growth at the base of the nest site discouraged bluebird nestings. Mountain Bluebirds occupied boxes which did not afford a nearby perch more often than did Eastern Bluebirds. Two such nestings were recorded for Mountain 
TABLE 1 Trends in relative bluebird populations on the nest line, 1963-1968

\begin{tabular}{|c|c|c|c|c|c|c|}
\hline & 1963 & 1964 & 1965 & 1966 & 1967 & 1968 \\
\hline $\begin{array}{l}\text { Number of boxes checked } \\
\text { Number of total checked }\end{array}$ & 749 & 740 & 774 & 801 & $1200^{*}$ & $1400 \dagger$ \\
\hline that were bluebirds (a) & 50 & 79 & 106 & 126 & 215 & 302 \\
\hline $\begin{array}{l}\text { Per cent of total checked } \\
\text { that were bluebirds }\end{array}$ & 6.7 & 10.7 & 13.7 & 15.8 & 17.9 & 21.3 \\
\hline $\begin{array}{l}\text { Number of total checked } \\
\text { that were currocoides }\end{array}$ & 28 & 50 & 66 & 79 & 160 & 242 \\
\hline $\begin{array}{l}\text { Number of total checked that } \\
\text { were sialis } \\
\text { Per cent of bluebird total }\end{array}$ & 22 & 29 & 40 & 47 & 55 & 60 \\
\hline $\begin{array}{l}\text { that were currocoides (b) } \\
\text { Per cent of bluebird total }\end{array}$ & 56.0 & 63.3 & 61.9 & 62.7 & 74.4 & 80.1 \\
\hline $\begin{array}{l}\text { that were sialis } \\
\text { Per cent of total boxes }\end{array}$ & 44.0 & 36.7 & 38.1 & 37.3 & 25.6 & 19.9 \\
\hline $\begin{array}{l}\text { checked that were currocoides } \\
\text { Per cent of total boxes }\end{array}$ & 3.7 & 6.8 & 8.5 & 9.9 & 13.3 & 17.3 \\
\hline $\begin{array}{l}\text { checked that were sialis } \\
\text { (a) = first brood nestings only } \\
\text { (b) = figured on first brood nest } \\
*=\text { approximate, due to Tree Sy } \\
\dagger=\text { although the Annual Report } \\
\text { figure includes an approxima }\end{array}$ & $\begin{array}{l}\text { rs on } \\
\text { low e } \\
\text { or } 19\end{array}$ & 3.9 & 5.0 & 5.9 & 4.6 & 4.3 \\
\hline
\end{tabular}

Bluebirds in the Camp Hughes area in 1969 .

The above factors suggest that sialis is more selective than currocoides in terms of nesting requirements. It is therefore reasonable to presume that the species would suffer in the light of increasing nest competition (see "Nest competition ..."), since their specialized requirements are not usually met.

In addition to the above problem, bluebirds face a scarcity of natural nest sites in southwestern Manitoba. Near Camp Hughes, for example, natural sites are few because aspens rarely grow large enough to provide them. Formerly, this was not a serious problem, since telephone poles and fence posts often held cavities (Lane, pers. comm., 1969; also see Bird, 1961:94). At present, however, the frequent replacement of decaying telephone and fence posts eliminates this vital source of nest sites.

2) Nest competition and predation

Nest competition caused sialis much difficulty in securing a nest site. Major competition was with Mountain Bluebirds and Tree swallows (Irido- procne bicolor). It is significant that neither bluebird species would nest in a box holding an old clutch of eggs of another species. Mountain Bluebirds were less affected by Tree Swallow competition for reasons discussed under "Spring migration ..."

Bluebirds of both species competed with House Wrens (Troglodytes aedon) which victimized nests near woodlands. On several occasions, I have observed abandoned nests of bluebirds which contained clutches of punctured eggs, and I suspect wrens were responsible.

House Sparrows (Passer domesticus) and Deer Mice (Peromyscus maniculatus) were also a problem for both bluebird species. Leslie Nortl (pers. corr., 1969) reports an unusual case of Deer Mouse competition at Pratt, where mice drove a pair of Mountain Bluebirds from a box, and built under the bluebird nest. Normally, Deer Mice simply appropriate unused boxes. Swenson (1968) has raised the possibility that Deer Mice may be serious competitors for Mountain Bluebirds in some areas of Montana. It is interesting to note that 
in southwestern $\mathbf{M}$ anitoba, boxes appropriated by Deer Mice were almost always erected on rough fence posts, enabling the rodents to climb them. Because bluebirds naturally nest at higher elevations than those of boxes on the nest line (Godfrey, 1966, gives a range of 3 to 30 feet for sialis), it is questionable whether mice are significant nest competitors for bluebirds nesting in natural cavities in this region.

Starling (Sturnus vulgaris) have become more of a threat in recent years. At least two pairs occupied boxes on the nest line in 1968, and in 1969 there were more cases (see Randall and Lane, 1969). In 1969 at Camp Hughes a pair of Starlings drove out a pair of nesting Mountain Bluebirds. Leslie North referred to Starling competition at Pratt, and Mrs. N. Brooks (pers. corr., 1969) reports that on her farm near Hamiota, "every old woodpecker hole" is occupied by Starlings.

One instance of predation upon Eastern Bluebirds by an Eastern Chipmunk (Tamias striatus) was noted near Carberry (Miller, 1968).

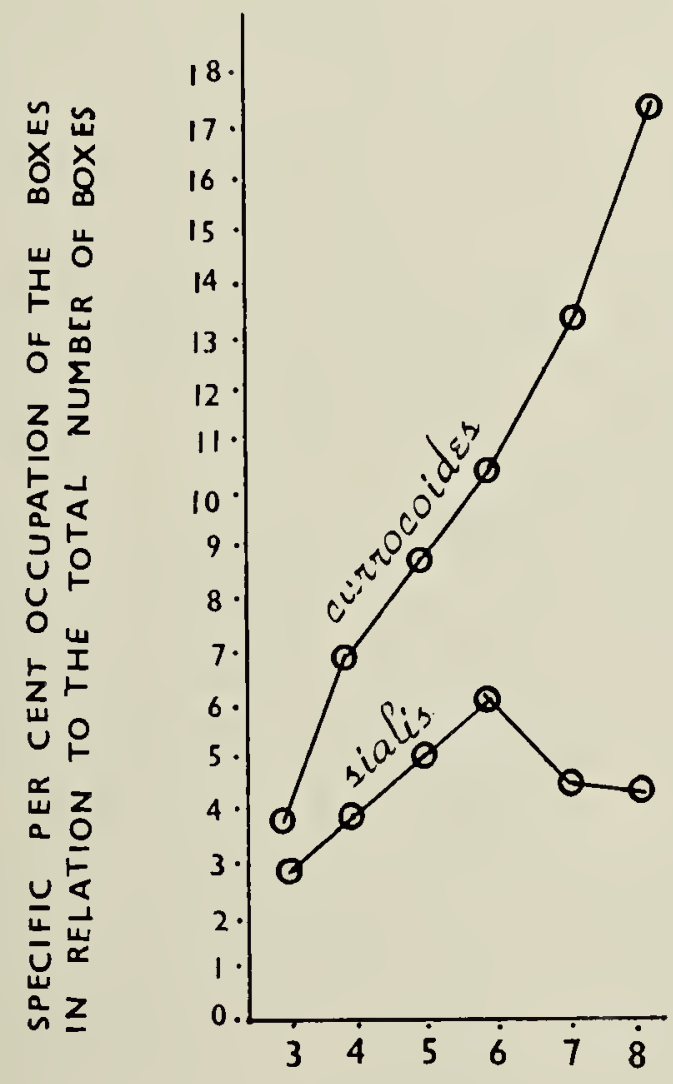

YEAR $(196 \ldots)$

Fig. 2. Population growths of Mountain and Eastern bluebirds on the nest line, 1963-1968.
Because of such competition, it may be that many pairs of Eastern Bluebirds go without nesting for entire seasons. In 1967, for example, several pairs began nesting as late as June 29 near Camp Hughes apparently because cavities could not be obtained sooner. (Boxes were recently erected in the area. The possibility that these birds were second-brood nesters is unlikely since most Eastern Bluebirds in the area were engaged in first brood nestings, and since Eastern and Mountain bluebirds generally renest in the box used for the first brood or in a neighboring box.) The aforesaid nests were later abandoned for unknown reasons. The belief that Eastern Bluebirds were desperate for nest sites is supported by the following observation: On June 11, 1968, just east of Camp Hughes, Mr. John Lane and I watched an Eastern Bluebird pair enter box No. 85 less than five minutes after its erection, after some conflict with an interested Mountain Bluebird male, which may have commanded a nearby territory.

3) Spring migration and spring weather conditions

Early spring arrival for Mountain Bluebirds gives the species a decided advantage over Tree Swallows and Eastern Bluebirds in securing a territory and nest site. The mean first arrival dates for Brandon, 1963-1969, for these three species are:

Mountain Bluebird ........ March 27

Eastern Bluebird.............April 19

Tree Swallow.................April 27

Although the first Eastern Bluebirds appear before Tree Swallows, the majority arrive after both Mountain Bluebirds and Tree Swallows have begun nesting. Whereas currocoides migration is generally complete by late April, sialis is often still arriving in early June. This migration behaviour accounts, in part, for the difficulty sialis has in securing a nest site (see "Nest requirements ..." . . If the percentage of Eastern Bluebirds which attain to reproduction is lower than with Mountain Bluebirds, as suggested by the apparent surplus of Easterns at Camp Hughes in 1967 and 1968, then late 
spring arrival along with the saturation of breeding territories by Mountain Bluebirds and Tree Swallows offers an explanation for this phenomenon.

Eastern Bluebirds compensate for late migration by arriving already paired, making it possible to undertake a nesting upon or soon after arrival. This behaviour varies with currocoides: Criddle (1927:40) reported that male Mountain Bluebirds preceded females by several days at Treesbank, Manitoba. On the other hand, I noted birds in pairs upon their arrival at Griswold in 1968.

Early spring migration subjects Mountain Bluebirds to hazardous weather conditions which the later arriving Easterns do not experience. In 1965 and 1968, for example, snow storms destroyed entire first clutches of Mountain Bluebirds throughout the nest line. Leslie North (pers. corr., 1969) writes that in one such storm, "more than one bluebird was found dead in the boxes." This is significant since North maintains only about 20 boxes near Pratt, Manitoba. The number of Mountain Bluebirds affected by these storms depends upon the date of the storm and its severity. Severe storms cause a noticeable delay in the nesting activities not only through adult mortality, but by frightening the females off the nests long enough for the eggs to chill. Earlier storms have less effect, since the number of bluebirds engaged in nesting is small, and since nesting is not advanced sufficiently to suffer drastic set-backs.

It might be argued that because southwestern Manitoba is on the western edge of the Eastern Bluebird's range in Canada, few pairs are attracted to nesting areas. Again, in view of the apparent surplus of Easterns in areas such as Camp Hughes (see "Nest competition ..."), this is probably not a dominant factor in regulating the populations of bluebirds in southwestern $M$ anitoba although this hypothesis may certainly apply to some areas of Saskatchewan.

\section{4) Nest care and aggression}

Nest care and defence of the nest is considerably stronger for currocoides. On numerous occasions, male Mountain Bluebirds launched into vigorous attacks when I visited the nests, the severity of which was in direct proportion to the stage of nest development. (For a description of the defence mechanisms of Mountain Bluebirds, see Power, 1966). Contrastingly, I rarely saw male Eastern Bluebirds put forth aggressive defence under these circumstances. Perhaps human intrusion is not regarded as a serious threat to the nest, since sialis can show remarkable concern for the young (see Miller, 1968).

Female Mountain Bluebirds also displayed more concern for the nest. and young than Eastern females. Usually Mountain females would assist the males in defending the nest against intrusion, whereas this was very unusual for Eastern Bluebird females. Many times in checking the nest boxes it was necessary to lift currocoides females from the nests to count eggs or young. Only once during my studies at Camp Hughes in 1969 did an Eastern female sit so tightly.

In 1967 and 1968, several unmated male Eastern Bluebirds commanded inactive nest sites. The fact that these birds could retain such nests for entire seasons in spite of competition is significant. Perhaps the presumed shortage of nest sites for sialis is not great, suggesting that other factors besides a limitation of nest sites contributed to the decline of sialis in 1967 and 1968.

In contrast to the above, I have not seen solitary male Mountain Bluebirds defending inactive nest sites, although males will care for the young should the female be killed. Leslie North, of Pratt, reports one such instance for 1968 (pers. cor., 1969).

Mr. John Lane observed a solitary female Mountain Bluebird caring for an active nest near Camp Hughes in 1968 and recalls cases of similar behaviour for Eastern Bluebird females for the same year.

Mountain Bluebirds are generally more aggressive than Easterns, and are capable of evicting already nesting pairs of Eastern Bluebirds. On 
June 6,1969 , I saw a Mountain Bluebird male engaged in conflict with a male Eastern at box No. 858 at Camp Hughes. Prior to that date the box had been occupied by Easterns, so presumably this was the Eastern male defending his own territory. A female sat nearby while the two males struggled and clawed on the ground. The Mountain Bluebird was definitely the aggressor, and used the tactic of "flying in pursuit" many times (after Power, 1966). When the box was visited on a later date, Mountain Bluebirds had built a nest and had laid five eggs. There was no sign of the Easterns. Although instances such as the above do not provide sufficient evidence to conclude that currocoides regulates sialis numbers on the nest line, they do suggest the possibility.

It is interesting to compare the above with observations made on a nest line harbouring Eastern Bluebirds only. Herb Copland (pers. corr., 1969) writes that on a nest line consisting of 22 operative boxes near Vivian, Manitoba, none of which are occupied by Mountain Bluebirds, the nest care of Eastern Bluebirds is quite strong in many instances. $\mathrm{He}$ reports cases of having to lift a female Eastern from the box to count the young, of being mobbed by adult Easterns when at the box, and of "agitated" adults. He comments, "It would also seem that the female Eastern Bluebirds refuse to leave the nestbox . . . because the eggs are either heavily incubated and near the point of hatching or they are brooding newly hatched young." Indeed, such statements might well apply to Mountain Bluebirds in southwestern Manitoba on the nest line. This leads one to suspect that the degree of nest care and aggression varies in Eastern Bluebirds from one area to another. It may be that in areas of range overlap such as southwestern Manitoba, the presence of currocoides represses these qualities, although the mechanisms of this repression are not clear.

5) Nest success and second brood nestings

During the nesting season of 1969 ,
I sampled the Camp Hughes study area to compare the nesting successes of Mountain and Eastern bluebirds. Only first brood nestings were considered in this facet of the study. The results are outlined in Table 2 .

The unusually high incidence of vandalism at Camp Hughes may have caused the nesting success for currocoides to be slightly low in comparison to other areas on the nest line. It is interesting to note that no nest failures for Eastern Bluebirds are attributable to vandalism. This reflects the tendency of Eastern Bluebirds to choose more secluded nest sites than Mountain Bluebirds.

Nice $(1957: 308)$, in her studies of nesting success for some hole-nesting altricial birds, recorded hatch rates for sialis ranging between 63.0 per cent and 80.1 per cent (averaging 71.5 per cent). The 58 per cent figure for Camp Hughes therefore seems to be abnormally low. This raises the possibility that various influences such as pesticides may have lowered the hatch rates for sialis in southwestern Manitoba in the past decade or so, assuming that Nice's figures provide a suitable norm, and assuming that the Camp Hughes figure reflects the nesting success of sialis in other areas of southwestern Manitoba.

Notice that in spite of the lower hatch rate for currocoides, the species has a larger average-sized clutch than sialis.

The nest success figures do not provide a complete picture, inasmuch as the majority of Mountain Bluebirds attempt second brood nestings whereas this is unusual for Eastern Bluebirds. Power (1966) found that 50 per cent of Mountain Bluebird pairs attempted second broods in Montana. Examining his data, we can derive that second brood nestings are about 77 per cent as successful as first brood nestings. If such is the case in southwestern Manitoba, then it follows that Mountain Bluebirds would have a considerably higher nest success rate per annum than Eastern Bluebirds. Also, Randall and Lane (1969) have suggested that more than 50 per cent 
TABLE 2 Nest success survey, Camp Hughes, 1969

\begin{tabular}{|c|c|c|c|c|c|}
\hline $\begin{array}{l}\text { Box } \\
\text { No. }\end{array}$ & $\begin{array}{l}\text { Approx. Date } \\
\text { Clutch } \\
\text { Complete }\end{array}$ & $\begin{array}{l}\text { No. } \\
\text { Eggs } \\
\text { Laid }\end{array}$ & $\begin{array}{l}\text { No. } \\
\text { Eggs } \\
\text { Hatched }\end{array}$ & $\begin{array}{l}\text { No. } \\
\text { Young } \\
\text { Fledged }\end{array}$ & Comments \\
\hline \multicolumn{6}{|c|}{ A. Mountain Bluebird } \\
\hline 233 & $5-5$ & 6 & 5 & 5 & \\
\hline 871 & $5-12$ & 6 & 6 & 6 & \\
\hline 1100 & $5-8$ & 6 & 5 & 5 & \\
\hline 839 & $5-22$ & 7 & 7 & 7 & \\
\hline 726 & before $5-11$ & 5 & 0 & 0 & -cause of failure unknown \\
\hline 949 & $5-14$ & 7 & 6 & 5 & \\
\hline 345 & & 0 & 0 & 0 & -box taken over by Starlings \\
\hline 885 & $5-10$ & 6 & 0 & 0 & —vandalized \\
\hline 555 & $5-10$ & 7 & 7 & 6 & \\
\hline 465 & $\ldots \ldots$ & 5 & 0 & 0 & $\begin{array}{l}\text {-box taken over by Tree } \\
\text { Swallows }\end{array}$ \\
\hline 881 & $5-9$ & 5 & 0 & 0 & —vandalized \\
\hline $85 \mathrm{C}$ & $5-15$ & 6 & 4 & 0 & - cause of failure unknown \\
\hline 860 & $5-8$ & 6 & 4 & 4 & \\
\hline 880 & $5-12$ & 6 & 0 & 0 & -cause of failure unknown \\
\hline 882 & $5-13$ & 6 & 0 & 0 & —cause of failure unknown \\
\hline 82 & $5-10$ & 6 & 0 & 0 & —vandalized \\
\hline 67 & $5-10$ & 5 & 4 & 3 & \\
\hline 32 & $5-9$ & 6 & 6 & 6 & \\
\hline 546 & before $5-25$ & 5 & 5 & 5 & \\
\hline \multicolumn{6}{|c|}{ B. Eastern Bluebird } \\
\hline 341 & $5-6$ & 5 & 3 & 3 & \\
\hline 544 & before $5-30$ & 3 & 0 & 0 & —all eggs infertile \\
\hline 496 & $5-11$ & 4 & 1 & 0 & -3 eggs infertile \\
\hline 663 & $5-11$ & 6 & 5 & 5 & \\
\hline 916 & $5-9$ & 6 & 5 & 5 & \\
\hline \multirow{4}{*}{\multicolumn{3}{|c|}{$\begin{array}{l}\text { FERTILITY RATES } \\
\text { Total number eggs laid } \\
\text { Total number eggs hatched } \\
\text { Fertility rate }\end{array}$}} & \multicolumn{3}{|c|}{ Mountain Bluebird (a) Eastern Bluebird (b) } \\
\hline & & & \multirow{2}{*}{\multicolumn{3}{|c|}{$\begin{array}{ll}88 & 24 \\
59 & 14\end{array}$}} \\
\hline & & & & & \\
\hline & & & \multicolumn{3}{|c|}{$73 \% \quad 58 \%$} \\
\hline
\end{tabular}

(a) - excluding boxes $885,345,465,881,882$, and 82 , since it is unknown how many eggs would have hatched had incubation not been disrupted.

(b) - including all boxes, since failures were the result of infertile eggs.
HATCH RATES (c)
Total eggs laid
Total hatch
Hatch rate
Mountain Bluebird
116
59
$51 \%$
24
14
$58 \%$

Eastern Bluebird

(c) -including all boxes, since vandalism, etc. are definite factors regulating hatch rates throughout the entire nest line.
NEST SUCCESS RATES
Tortal eggs laid
Total young fledged
Success rate
Mountain Bluebird
Eastern Bluebird
116
24
52
13
$45 \%$
$54 \%$

of Mountain Bluebird pairs attempt second brood nestings in southwestern Manitoba. This is certainly true at Camp Hughes, judging from the large number of birds engaged in nesting throughout this area in July and August. It can be concluded that the overall nest success of Mountain Bluebirds is a major factor contributing to the phenomenal rise in numbers of 
TABLE 3 Further trends in relative populations of bluebirds on the nestline.

\begin{tabular}{lrrrrrr}
\hline Year & 1963 & 1964 & $1 \Xi 65$ & 1966 & 1967 & 1968 \\
\hline Number of boxes available & 749 & 740 & 774 & 801 & 1200 & 1400 \\
Number that were currocoides & 28 & 50 & 66 & 79 & 160 & 242 \\
Number that were not & & & & & & \\
$\quad$ currocoides & 721 & 690 & 708 & 722 & 1040 & 1158 \\
Number that were sialis & 22 & 29 & 40 & 47 & 55 & 50 \\
$\begin{array}{l}\text { Per cent that were not } \\
\quad \text { currocoides that were }\end{array}$ & & & & & & \\
$\quad$ used by sialis & $3.1 \%$ & $4.2 \%$ & $5.6 \%$ & $6.5 \%$ & $5.3 \%$ & $5.2 \%$ \\
\hline
\end{tabular}

that species in recent years, not only near Camp Hughes, but possibly throughout southwestern Manitoba.

\section{Discussion}

As shown in Figure 2, both bluebird species increased fairly constantly up to 1966. In 1967 and 1968, however, currocoides accelerated its rate of population growth whereas sialis decelerated markedly. These trends indicate that factors not evident before 1966 influenced the population growth of sialis and currocoides thereafter. Apparently, these factors were introduced as a result of population increase of both species up to 1966 , and possibly because of a limited number of nest sites. Assuming that this was the case, then it seems reasonable to consider an increase in interspecific interaction as one possible factor. Unfortunately, this report supplies no direct evidence that the number of suitable nest sites for bluebirds was limited.

Table 3 shows that there is always a large surplus of nest boxes not used by bluebirds. The figures from 1963 to 1966 indicate that sialis can use at least 6.5 per cent of the nest boxes not used by currocoides. In 1967 and 1968 , sialis used less than this proportion. Because there is no evidence to suggest that this percentage is influenced by currocoides, we can assume that sialis is capable of commanding at least 6.5 per cent of all boxes not occupied by currocoides. Why, then, did this proportion fall below this figure to 5.3 per cent in 1967 and 5.2 per cent in 1968 ? Two alternatives are:

1) Because of other influences besides competition with currocoides, the prercentage of nests not used by currocoides that could be used by sialis was lowered, excluding some pairs of sialis from breeding.

2) For whatever factors that were responsible for producing the number of breeding pairs that showed up in 1967 and 1968, there were insufficient Eastern Bluebirds to use all of the available nest sites in excess of those used by Mountain Bluebirds.

The first hypothesis assumes that the number of suitable nest sites was limited, in order that sialis would be excluded from breeding. The much better response of currocoides to large increases in nest boxes (Table 2), suggests that if either species was significantly limited by a lack of nest sites prior to 1967, it was currocoides rather than sialis. However, the fact that currocoides arrives earlier than sialis and Tree Swallows refutes this conclusion, since currocoides would have first choice of the available nest sites. But in view of the increase in the number of boxes that were not occupied by currocoides, especially in 1967 and 1968, and considering that the "other influences" of the first hypothesis would have had to be drastic in nature to reverse the trends in population growth of sialis to such an extent, the first hypothesis does not furnish a complete solution. On the other hand, the second hypothesis does not account for the apparent surplus of Eastern Bluebirds in such areas as Camp Hughes in 1967 and 1968, no matter how insignificant this surplus may have been. It may well be that, as in the second hypothesis, various factors diminished the sialis numbers returning in 1967 and 1968, and in addition, other influences such 
as an increase in competition with species other than currocoides caused some of these returning birds to be excluded from breeding. At any rate, both of the proposed hypotheses indicate that territorial interactions and competition with currocoides are not necessarily critical influences regulating sialis populations in southwestern Manitoba in recent years.

The above discussion is based on the criterion that any limitation of nest sites would affect the entire nest line. It is therefore necessary to explore the possibility that lack of nest sites may be a localized problem. It is known that many areas on the nest line do not meet the habitat requirements of bluebirds, and therefore do not harbour either species. In spite of the many unused nest sites in such areas, any limitation of nest sites in one of the major breeding locations for bluebirds, such as Camp Hughes or Grand Glariere, could have profound effects on sialis numbers. In 1967 and 1968, for example, Camp Hughes held an unusually high concentration of bluebirds early in the breeding season, and it seemed obvious that late returning Eastern Bluebirds would either not find nests, or relocate. In those years, not a great deal of redistribution of sialis populations occurred on the nest line, and as a result, pairs of sialis apparently excluded from breeding were in evidence. The decline in the percentage of total nest boxes used by sialis in 1967 and 1968 at a time when populations of currocoides increased markedly (see Table 1 or Figure 2) suggests that a phenomenon of localized control of sialis numbers by currocoides may have occurred in southwestern Manitoba at that time. Conclusive evidence, however, remains lacking.

This report indicates that currocoides is dominant over sialis in interspecific strife and territorial disputes. This supports the belief that where nest sites are a limiting factor in regions of overlap between these species, breeding populations of sialis might to some extent be limited by high concentrations of currocoides.
Lack of suitable nest sites may well be the primary cause of population decline for currocoides in other parts of its range (see Power, 1966), for simply alleviating this problem in southwestern Manitoba caused a population expansion.

\section{Acknowledgments}

I would like to thank Mr. John Lane and the Brandon Junior Birders for their contribution to the field aspects of this project, and the following for comments and information: Mrs. N. Brooks, Herbert Copland, Martin McNicholl, Dr. Robert W. Nero, and Leslie North. I also want to acknowledge the help given by Dr. Roger M. Evans and Dr. Nero, both of whom critically reviewed the manuscript, and provided helpful suggestions.

\section{LITERATURE CITED}

Belcher, M. 1966. After 50 years, the Eastern Bluebird nests again at Regina. Blue Jay, $24: 18$ i-189.

Bird, R. D. 1961. Fcology of the aspen parkland of western Canada, Contr. No. 27, Res. Sta. Can. Dept. Agr. Winnipeg. 155pp.

Criddle, N. 1904. The Mountain Bluebird in Manitoba. Ottawa Nat., 18:85-86.

Criddle, N. 1927. Habits of the Mountain Bluebird in Manitoba. Can. Field-Nat., 41:40 44.

Cutforth, B. 1968. Eighth annual report of the Brandon juniors' nest-box project, 1968. Blue Jay, $26: 188$.

Godfrey, W. E. 1966. The birds of Canada. Nat. Mus. Can. Bull. 203, Biol. Ser. No. 73. Ottawa. 428 pp.

Lawrence, A. G. 1947. A westerner spreads eastwards, "Chickadee Notes", No. 1355, Winnipeg Free Press, May 9, 1947.

Miller, W. 1966. The annual report of the Brandon junior bird club's nest project. Blue Jay, $24: 197$.

Miller, W. 1968. Predation of bluebirds by an Eastern Chipmunk. Blue Jay, $26: 145$

Nice. M. M. 1957. Nesting success in altricial birds. Auk. 74:305-321.

Patterson, R. 1965. The annual report of the Brandon junior bird club's nest project. Blue Jay, $23: 182$.

Peters, B. 1964. 1964 report of the Brandon juniors' bird nest project. Blue Jay, $22: 162$.

Plews, D. 1963. 1963 report of the Brandon bird clubs' nest project. Blue Jay, $21: 151$.

Power, H. W. 1966. Biology of the Mountain Bluebird in Montana. Condor, 68:351-371.

Randall, O., and J. Lane. 1969. Ninth Annual Report of the Brandon juniors' nestbox project. Blue Jay, $27: 215$.

Rourke, L. 1968. Annual report of the Brandon juniors' nestbox projects. Blue Jay, $26: 21$.

Swenson, J. E. 1968. The Deer Mouse as a nest competitor and possible predator on the Mountain Bluebird. Blue Jay, $26: 214$.

Thompson, E. E. (-E. T. Seton) 1891. The birds of Manitoba. U.S. Nat. Mus. Vol. 13, 1890 , pp. 475-643, Washington.

Thompson, E. E. (=E. T. Seton) 1893. Additions to the list of Manitoba birds. Auk, $10: 49-50$. 